\title{
High- and low-latitude climate control on the position of the southern Peru-Chile Current during the Holocene
}

\author{
Frank Lamy, Carsten Rühlemann, Dierk Hebbeln, and Gerold Wefer \\ Fachbereich Geowissenschaften, Universität Bremen, Bremen, Germany \\ Received 23 October 2001; revised 21 March 2002; accepted 21 March 2002; published 29 June 2002.
}

[1] We reconstructed changes of temperature, salinity, and productivity within the southern Peru-Chile Current during the last 8000 years from a high-resolution sediment core recovered at $41^{\circ} \mathrm{S}$ using alkenones, isotope ratios of planktic foraminifera, biogenic opal, and organic carbon. Paleotemperatures and paleosalinities reached maximum values at $\sim 5500$ years ago and thereafter declined to modern values, whereas paleoproductivity continuously increased throughout the last 8000 years. We ascribe these long-term Holocene trends primarily to latitudinal shifts of the Antarctic Circumpolar Current (ACC). The concurrence with shifts in the position of the Southern Westerlies points to a common response of atmospheric and oceanographic circulation patterns off southern Chile. Millennial- to centennial-scale fluctuations of paleotemperatures and paleosalinities, on the other hand, lag displacements in the position of the Southern Westerlies but reveal a significant correlation to short-term temperature changes in Antarctica, indicating a high-latitude control of the ACC at these timescales. INDEX TERMS: 3344 Meteorology and Atmospheric Dynamics: Paleoclimatology; 4267 Oceanography: General: Paleoceanography; 9355 Information Related to Geographic Region: Pacific Ocean; 1050 Geochemistry: Marine geochemistry (4835, 4850); 1040 Geochemistry: Isotopic composition/chemistry; KEYWORDS: SE Pacific, paleoceanography, paleoclimate, alkenones, paleosalinity

\section{Introduction}

[2] Eastern boundary currents (EBC) play a major role in the surface circulation of the global ocean. Besides being the biologically most productive oceanic regions of the world, the strong advection and upwelling of cold water also significantly control the climate conditions on the adjacent continents. Among the EBCs the Peru-Chile Current (PCC) stands out with an extension of over $40^{\circ}$ of latitude $(\sim 4500 \mathrm{~km})$ and an exceptionally high productivity supporting an intensive pelagic fishery [Alheit and Bernal, 1993]. In order to understand the functioning of this EBC system and, in turn, past and future climate changes in South America, a profound knowledge of the paleoenvironmental history of the PCC is a major prerequisite.

[3] As yet, the forcing mechanisms of past oceanographic changes within the PCC system are not well known because paleoceanographic proxy records from this ocean region are rare. Recent studies concentrate on the central Chilean part of the PCC $\left(33^{\circ} \mathrm{S}\right)$ where significant paleotemperature [ Kim et al., 2002], paleoproductivity [Marchant et al., 1999; Hebbeln et al., 2002; Klump et al., 2001], and continental rainfall changes [Lamy et al., 1999] occurred during the last 33,000 years. Low paleotemperatures and increased paleoproductivity generally paralleled more humid conditions in the continental hinterland, e.g., during the Last Glacial Maximum, pointing to a strong link of atmospheric (i.e., the position of the Southern Westerlies) and oceanographic (i.e., advection of cold nutrient-rich surface waters by the PCC) processes off central Chile.

Copyright 2002 by the American Geophysical Union. 0883-8305/02/2001PA000727\$12.00
[4] A key area to obtain a better understanding of forcing mechanisms and links between paleoenvironmental changes within the PCC system and on the adjacent continent is the southernmost PCC $\left(\sim 40^{\circ} \mathrm{S}\right)$ as the direct northward continuation of the Antarctic Circumpolar Current (ACC) (Figure 1). Strong latitudinal gradients in both modern sea surface temperature (SST) and sea surface salinity (SSS) [Brandhorst, 1971; Levitus and Boyer, 1994] make this region very sensitive to temperature and salinity changes in the past. Together with the advection of nutrients by the ACC, high river discharge causes a very high productivity in the southernmost PCC, which is even more pronounced than in the upwellingdominated parts of the PCC off central and northern Chile [Hebbeln et al., 2000]. Additionally, extremely high sedimentation rates due to high terrigenous sediment input in this region provide the opportunity to study the paleoenvironmental history with high temporal resolution. A previous study on the Holocene record of the terrigenous sediment input in this region revealed significant variations of continental rainfall on millennial to multicentennial timescales which were controlled by shifting latitudinal positions of the southern westerly wind belt related to changes within both the tropics and around Antarctica [Lamy et al., 2001].

[5] In this paper, we reconstruct the paleoceanographic history of the southern PCC during the last $\sim 8000$ years based on a multiproxy approach including paleotemperature and paleosalinity reconstructions derived from alkenone and planktic foraminiferal oxygen isotope data as well as paleoproductivity proxies (opal and organic carbon). We suggest that long-term Holocene paleoceanographic changes are primarily caused by latitudinal shifts of the ACC 

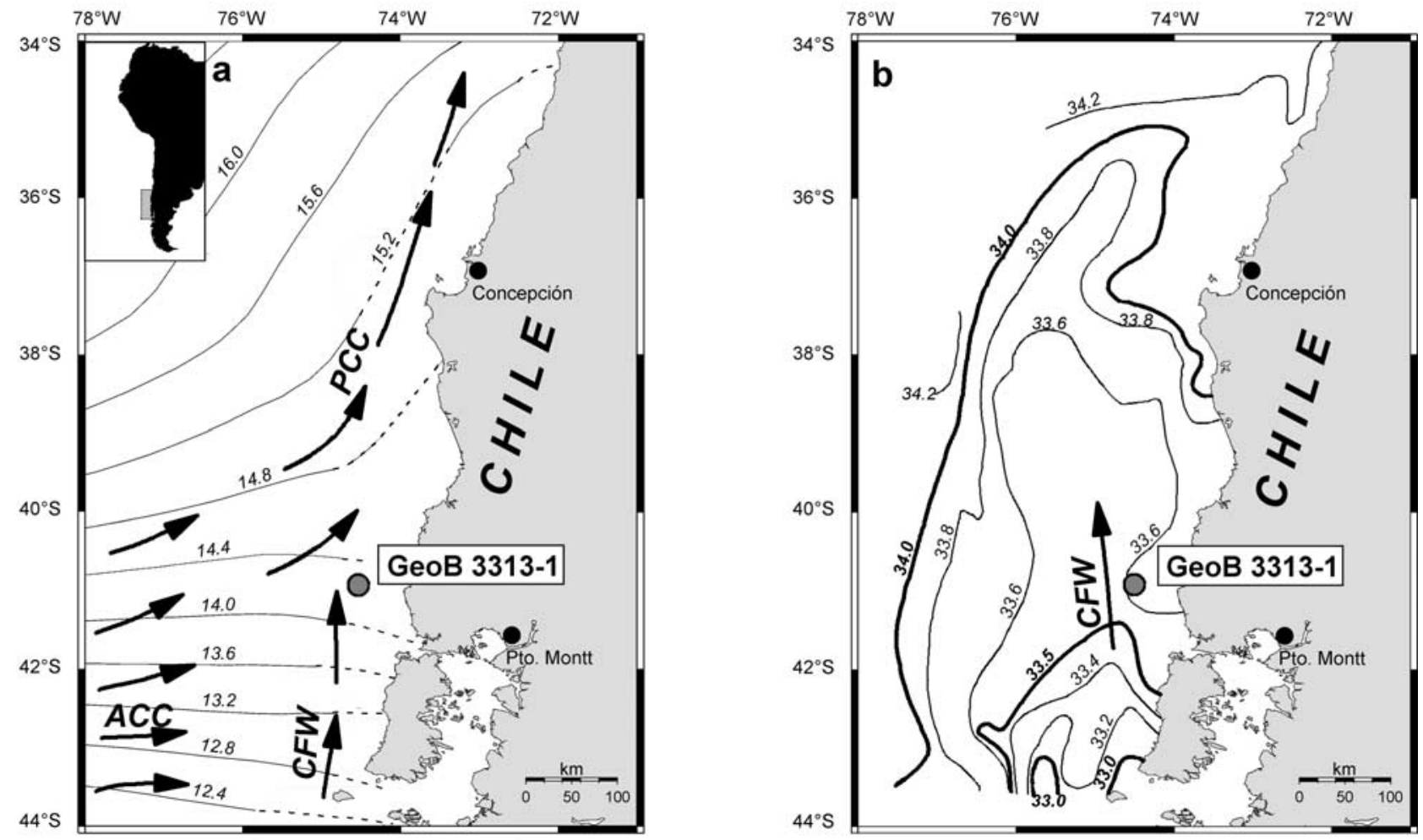

Figure 1. Maps of southern to central Chile and the adjacent southeastern Pacific showing oceanographic features (ACC, Antarctic Circumpolar Current; PCC, Peru-Chile Current; CFW, Chilean Fjord Water) after Strub et al. [1998] and location of core GeoB 3313-1 on the continental slope at $\sim 800 \mathrm{~m}$ water depth. (a) Modern mean annual SSTs (in ${ }^{\circ} \mathrm{C}$. after Levitus and Boyer [1994]; dashed isotherms are extrapolated). (b) Modern SSSs (in psu) measured during the Marchile cruise in February to March 1960 [Brandhorst, 1971].

which were synchronous to similar shifts of the southern westerly wind belt as reconstructed by Lamy et al. [2001]. On millennial to multicentennial timescales, fluctuations of paleotemperatures and paleosalinities lag latitudinal shifts of the Southern Westerlies but reveal a significant correlation to short-term temperature changes in Antarctica, indicating a dominant high-latitude control of the ACC at these timescales.

\section{Investigation Area}

[6] Marine sediment core GeoB 3313-1 was taken from a small marine basin at the upper continental slope at $\sim 41^{\circ} \mathrm{S}$ off southern Chile (Figure 1). In this region the large-scale oceanic surface circulation is controlled by the ACC transporting subantarctic water toward the Chilean coast between $40^{\circ}$ and $45^{\circ} \mathrm{S}$, where it splits into the poleward flowing Cape Horn Current and the equatorward flowing PCC [Strub et al., 1998] (Figure 1a). Mean annual latitudinal SST gradients are particularly pronounced in this area, increasing from $\sim 12^{\circ} \mathrm{C}$ at $45^{\circ} \mathrm{S}$ to $\sim 15^{\circ} \mathrm{C}$ at $40^{\circ} \mathrm{S}$ [Levitus and Boyer, 1994] (Figure 1a). The seasonal amplitude of SST at the core site is $\sim 5^{\circ} \mathrm{C}$. Farther north, latitudinal SST gradients diminish, and the isotherms run more longitudinally, marking the cold water advection by the PCC and the effects of strong coastal upwelling. An important hydrographic feature off southern Chile is the low-salinity surface water tongue originating from the high freshwater supply to the Chilean fjord region [Strub et al., 1998]. The low-salinity Chilean Fjord Water (CFW) flows northward within 150-200 km off the coast (Figure 1b).

[7] Prevailing onshore blowing winds of the Southern Westerlies prevent coastal upwelling off southern Chile [Strub et al., 1998]. Seasonal upwelling occurs only farther north, e.g., off Concepción $\left(37^{\circ} \mathrm{S}\right)$. Therefore high satellite pigment concentrations in southern Chilean waters [Thomas et al., 1994] are most likely due to a mixing of ironlimited high nutrient-low chlorophyll waters advected by the ACC and riverine micronutrients, such as iron, discharged into the Chilean fjord region [Hebbeln et al., 2000].

[8] The continental climate of the study area is controlled by the frequent passage of cyclonic storms originating from the Southern Westerlies. The area north of $42^{\circ} \mathrm{S}$ is characterized by successively decreasing summer rain gradually changing to the Mediterranean-type summer dry conditions in central Chile. South of $42^{\circ} \mathrm{S}$ a yearround supply of moist Pacific air masses results in extraordinary high precipitation. The location of the maximum storm tracks of the Southern Westerlies is related to the steepest SST gradients within the polar front, which is 


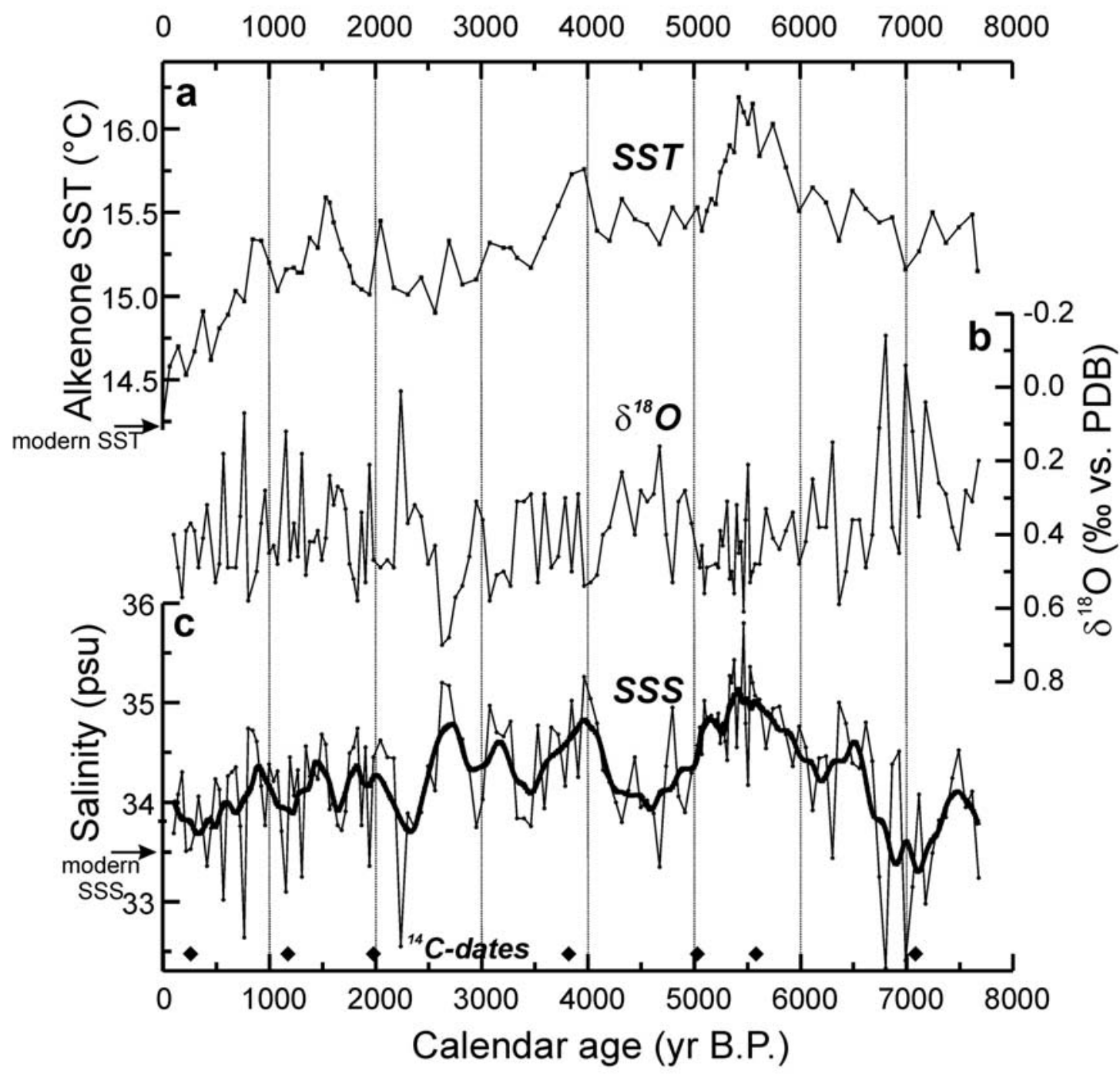

Figure 2. Sea surface temperature and salinity proxy data from core GeoB 3313-1 plotted versus calendar age. (a) Alkenone-based paleotemperature reconstruction. (b) Oxygen isotope record of the planktic foraminifera Neogloboquadrina pachyderma (dextral). (c) Calculated paleosalinity record (thick line is five-point moving average) with location of ${ }^{14} \mathrm{C}$ accelerator mass spectrometer (AMS) dates (diamonds).

located near $45^{\circ} \mathrm{S}$ off the coast of Chile [Streten and Zillman, 1984].

\section{Material and Methods}

\subsection{Sampling and Stratigraphy}

[9] Gravity core GeoB $3313-1\left(41^{\circ} 00^{\prime} \mathrm{S}, 74^{\circ} 27^{\prime} \mathrm{W}\right.$, water depth $852 \mathrm{~m}$, core length $807 \mathrm{~cm}$ ) was recovered from the upper continental slope off Chile during the German R/V Sonne cruise 102 [Hebbeln et al., 1995]. The sediments mainly consist of terrigenous material, dominated by clayey silts. Grain size and clay mineral analyses suggest that the sediments were deposited by hemipelagic processes without any significant contribution of turbidity currents or alteration by bottom currents [Lamy et al., 2001]. Sediments were sampled at $5 \mathrm{~cm}$ intervals for determinations of organic carbon $\left(\mathrm{C}_{\mathrm{org}}\right)$ contents and oxygen isotope composition of planktic foraminifera, at $10 \mathrm{~cm}$ intervals for alkenone analyses, and at $20 \mathrm{~cm}$ intervals for measurements of biogenic opal content. All data are archived in both the German Pangaea database and the paleoclimate database at the National Geophysical Data Center. ${ }^{1}$

[10] The age model for core GeoB 3313-1 has recently been published by Lamy et al. [2001] and is based on seven ${ }^{14} \mathrm{C}$ accelerator mass spectrometry (AMS) dates (Figures 2 and 3) and linear interpolation between these dates. The ${ }^{14} \mathrm{C}$ ages (Table 1) were converted to calendar years with the Calib 4.0 software [Stuiver and Reimer, 1993] and are reported as calendar years B.P. Sedimentation rates are in

\footnotetext{
${ }^{1}$ Supporting data are available electronically from the Pangaea Data Center, Bremerhaven, Germany (http://www.pangaea.de/home/flamy/), and from World Data Center-A for Paleoclimatology, NOAA/NGDC, 235 Broadway, Boulder, CO 80303, USA (e-mail: paleo@mail.ngdc.noaa.gov; URL: http:/www.ngdc.noaa.gov/paleo; FTP: ftp://ttp.ngdc.noaa.gov/paleo/ paleocean/by_contributor/lamy2002/).
} 


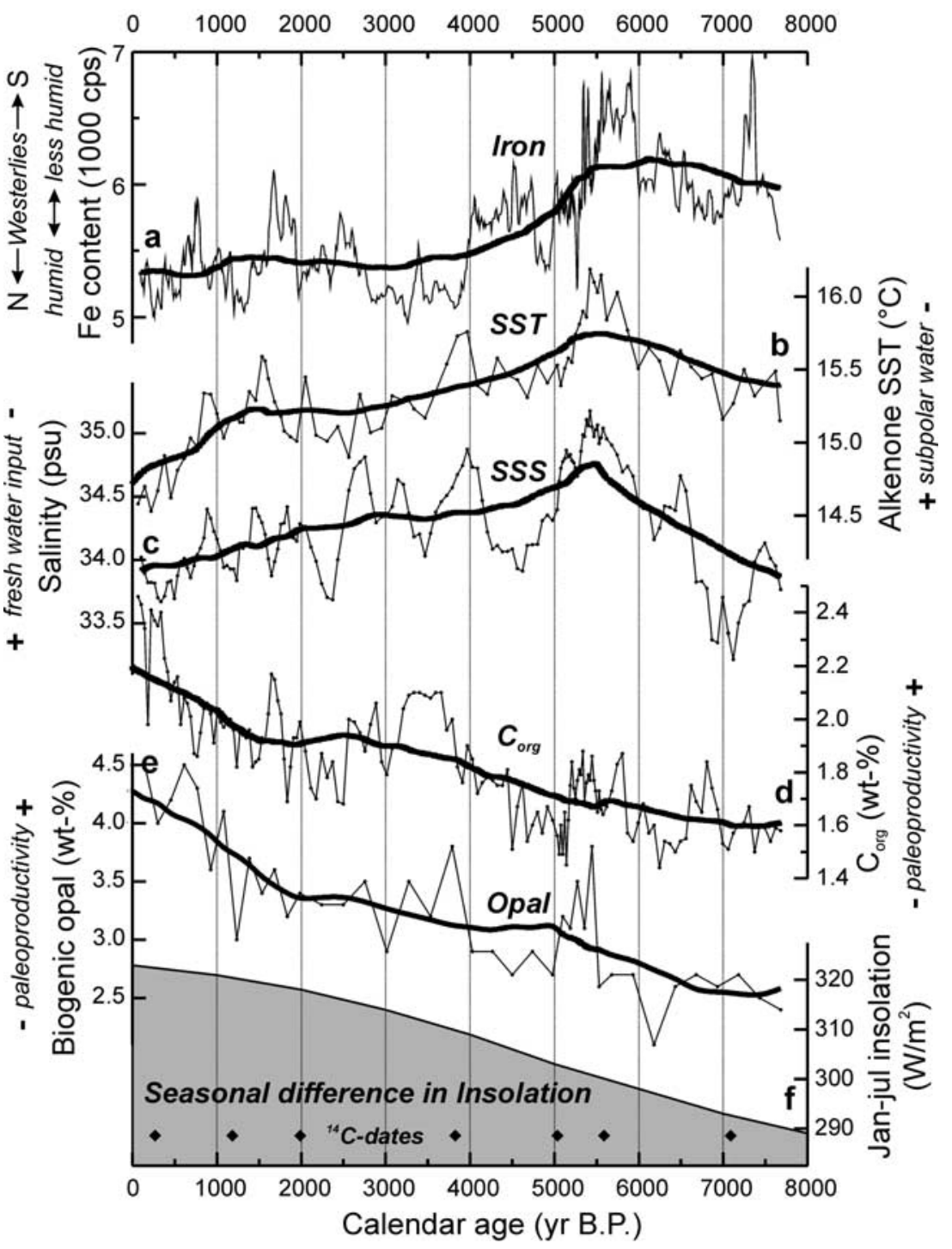

Figure 3. Compilation of paleoceanographic and continental paleoclimate records of core GeoB 3313-1 focusing on both long-term trends (thick lines are $\sim 2000$ year moving averages) and millennial- to multicentennial-scale variability during the last $\sim 8000$ years. (a) Iron contents of core GeoB 3313-1 [Lamy et al., 2001] interpreted as a proxy for rainfall and the position of the Southern Westerlies (fivepoint moving average). High iron contents imply increased contribution of iron-rich volcanic Andean source rocks and decreased supply of iron-poor Coastal Range source rocks. Such conditions indicate decreased rainfall, most likely induced by a southward shift of the Southern Westerlies (for further details, please refer to Lamy et al. [2001]). (b) Alkenone-based paleotemperature reconstruction that traces the advection of subpolar water by the ACC. (c) Paleosalinity reconstruction (five-point moving average) that delineates the advection of CFW. (d) $\mathrm{C}_{\text {org }}$ contents and (e) biogenic opal contents, taken as proxies for paleoproductivity. Biogenic opal and $\mathrm{C}_{\text {org }}$ contents are positively correlated $(r=0.82 ; n=41$; significant on the $99.9 \%$ level after applying a 200 year time resolution interpolation). (f) Seasonal insolation changes at $40^{\circ} \mathrm{S}$ after Berger and Loutre [1991].

the range of $100 \mathrm{~cm} / \mathrm{kyr}$ on average. The average time resolution for the paleoceanographic records is between 50 and 200 years, depending on the sampling interval.

\subsection{Alkenone Measurements}

[11] $\mathrm{C}_{37}$ alkenone ratios were determined on $2 \mathrm{~g}$ of freezedried and homogenized sediment using a HP 5890 series II gas chromatograph equipped with a cold on-column injector (for details, see Rühlemann et al. [1999]). For sea surface temperature reconstructions we used the simplified unsaturation index of $\mathrm{C}_{37}$ alkenones $\left(U_{37}^{K^{\prime}}=\left[\mathrm{C}_{37: 2}\right] /\left[\mathrm{C}_{37: 2+} \mathrm{C}_{37: 3}\right]\right)$. To convert from $U_{37}^{K^{\prime}}$ values to $\mathrm{SST}$, we applied the calibration of Prahl et al. $[1988]\left(T\left[{ }^{\circ} \mathrm{C}\right]=\left(U_{37}^{K^{\prime}}-0.039\right) / 0.034\right)$. Analytical precision $( \pm 1 \sigma)$ was better than $0.01 U_{37}^{K^{\prime}}$ units (or $0.3^{\circ} \mathrm{C}$ ). 
Table 1. The ${ }^{14} \mathrm{C}$ Dates Used to Constrain the Age-Depth Model for Core GeoB 3313-1

\begin{tabular}{ccccc}
\hline $\begin{array}{c}\text { Laboratory } \\
\text { Number }\end{array}$ & $\begin{array}{c}\text { Core } \\
\text { Depth, } \\
\text { cm }\end{array}$ & $\begin{array}{c}{ }^{14} \text { C AMS Age, } \\
\text { years B.P }\end{array}$ & $\begin{array}{c} \pm \text { Error, } \\
\text { years }\end{array}$ & $\begin{array}{c}\text { Calibrated Age, } \\
\text { calendar years } \\
\text { B.P. }\end{array}$ \\
\hline KIA 6794 & $33-43$ & 195 & 30 & 260 \\
KIA 6793 & $153-158$ & 1220 & 30 & 1180 \\
KIA 7231 & $258-268$ & 1970 & 50 & 1980 \\
KIA 5098 & $403-408$ & 3460 & 40 & 3820 \\
KIA 5097 & $503-513$ & 4390 & 40 & 5040 \\
KIA 7230 & $633-638$ & 4830 & 60 & 5590 \\
KIA 7229 & $753-758$ & 6170 & 80 & 7090 \\
\hline
\end{tabular}

\subsection{Oxygen Isotopes}

[12] Stable oxygen isotope measurements have been performed on 10-15 individual shells of the planktic foraminifer Neogloboquadrina pachyderma (dextral) (which is the most abundant planktic foraminifera along the Chilean continental slope [Hebbeln et al., 2000]), using a Finnigan MAT 251 mass spectrometer. The ratio of ${ }^{18} \mathrm{O} /{ }^{16} \mathrm{O}$ is given in per mil relative to the Peedee belemnite (PDB) standard. Analytical standard deviation is about $\pm 0.07 \%$ PDB (Isotope Laboratory, Bremen University).

\subsection{Paleoproductivity Proxies}

[13] Total organic carbon $\left(\mathrm{C}_{\text {org }}\right)$ contents were determined by combustion of $50 \mathrm{mg}$ subsamples of dried, homogenized, and decalcified sediment in a Hearaeus CHN-O-Rapid elemental analyzer. All analyses are given in weight percent dry, salt-free sediment assuming a pore water salinity of $35 \%$. The relative precision was $\pm 2 \%$ on the basis of repeated measurements of both standards and samples.

[14] Biogenic opal content of the sediment was determined using a sequential leaching technique (DeMaster [1981] modified by Müller and Schneider [1993]). Biogenic opal was extracted from ground sediment samples with $1 \mathrm{M}$ $\mathrm{NaOH}$ at $85^{\circ} \mathrm{C}$ during 1 hour. The concentration of dissolved silica was simultaneously measured by continuous flow analysis with Molybdate Blue spectrometry. The precision of the method is better than $\pm 0.5 \%$.

\subsection{Paleosalinity}

[15] The $\delta^{18} \mathrm{O}$ of planktic foraminifera mainly depends on the temperature and $\delta^{18} \mathrm{O}$ of ambient seawater $\left(\delta^{18} \mathrm{O}_{\mathrm{w}}\right)$. Since $\delta^{18} \mathrm{O}_{\mathrm{w}}$ is linearly related to salinity, it is possible to reconstruct paleosalinity if an independent estimate of temperature is available [Duplessy et al., 1991; Rostek et al., 1993]. Here we use the $\delta^{18} \mathrm{O}$ of the planktic foraminifer Neogloboquadrina pachyderma (dextral) and the alkenone temperature record for estimating paleosalinity variations. To match the more narrowly spaced foraminiferal $\delta^{18} \mathrm{O}$ record, we interpolated the alkenone-based SST data to $5 \mathrm{~cm}$ intervals. The SST estimate for the uppermost sample $\left(14.2^{\circ} \mathrm{C}\right)$ matches the modern annual mean SST value for the core site $\left(14.0^{\circ} \mathrm{C}\right)$ [Levitus and Boyer, 1994]. This is in agreement with other alkenone temperature analyses of surface sediments recovered north of our study site [Kim et al., 2002]. We thus consider that alkenones-derived SSTs correspond to the annual average at $0 \mathrm{~m}$ water depth. As the mean calcification depth of $N$. pachyderma in the study area is 30 m (F. Lamy, unpublished data, 2001), we subtracted an average of $0.5^{\circ} \mathrm{C}$ (the modern mean annual temperature difference between the sea surface and $30 \mathrm{~m}$ depth) from the alkenone record. We used the paleotemperature equation of Shackleton [1974] to reconstruct the $\delta^{18} \mathrm{O}_{\mathrm{w}}$ throughout the past 8000 years:

$$
T=16.9-4.38\left(\delta^{18} \mathrm{O}_{\text {carb }}-\delta^{18} \mathrm{O}_{\mathrm{w}}\right)+0.1\left(\delta^{18} \mathrm{O}_{\text {carb }}-\delta^{18} \mathrm{O}_{\mathrm{w}}\right)^{2},
$$

where $T$ is paleotemperature $\left({ }^{\circ} \mathrm{C}\right),\left(\delta^{18} \mathrm{O}_{\mathrm{w}}\right)=\delta^{18} \mathrm{O}$ of ambient seawater (per mil versus SMOW), and $\left(\delta^{18} \mathrm{O}_{\text {carb }}\right)=$ $\delta^{18} \mathrm{O}$ of carbonate $(N$. pachyderma (dextral)) (per mil versus PDB).

[16] To estimate local changes in paleosalinity from the $\delta^{18} \mathrm{O}_{\mathrm{w}}$ record, we applied the regional $\delta^{18} \mathrm{O}$-salinity relationship for the eastern equatorial Pacific by Fairbanks et al. [1992] (which has a similar slope as the regional $\delta^{18} \mathrm{O}$ salinity relationship for the SE Pacific as recently modeled by Delaygue et al. [2000]) resulting in equation (2):

$$
S=34.6+3.85\left(\delta^{18} \mathrm{O}_{\text {carb }}-21.9\right)+(310.6+10 T)^{-1},
$$

where $S$ is paleosalinity (practical salinity units (psu)), $T$ is paleotemperature $\left({ }^{\circ} \mathrm{C}\right)$, and $\left(\delta^{18} \mathrm{O}_{\text {carb }}\right)=\delta^{18} \mathrm{O}$ of carbonate (N. pachyderma (dextral)) (per mil versus PDB).

[17] We assume that the slope of the regional $\delta^{18} \mathrm{O}$ salinity relationship equation (2) did not change significantly throughout the last 8000 years, a factor which may strongly affect SSS reconstructions for the glacial ocean [e.g., Wolff et al., 1998]. Additional effects such as changing isotopic signatures of precipitation [Wolff et al., 1998] are unlikely because our study area is situated within or near the source region of rainfall derived from the westerly wind belt in the southeast Pacific.

\section{Results and Discussion}

\subsection{Proxy Records}

[18] Reconstructed paleotemperatures range from $14.2^{\circ}$ to $16.2^{\circ} \mathrm{C}$ and increase from the beginning of the record at $\sim 7800$ calendar years B.P. (7800 B.P.) toward maximum values around 5500 B.P. reaching $2^{\circ} \mathrm{C}$ above modern SSTs (Figure 2a). Thereafter, temperatures show a general cooling trend, especially during the last $\sim 1500$ years. Additionally, multicentury-scale paleotemperature variations appear throughout the record; the most prominent occur shortly after 4000 B.P. and at $~ 1550$ B.P.

[19] Paleosalinity estimates show variations between $\sim 33$ and $36 \mathrm{psu}$ with a significant scatter (Figure 2c). This scatter is obviously induced by the oxygen isotope data which vary between $\sim 0.6$ and $-0.15 \%$ o PDB without any pronounced long-term trend (Figure $2 \mathrm{~b}$ ). The values are within the range of $\delta^{18} \mathrm{O}$ data from surface samples off southern Chile [Hebbeln et al., 2000]. The scatter might be related to the environmental range of $N$. pachyderma (dextral), resulting in varying depth habitats and seasonal preferences of individual foraminifer specimens. In the following, we therefore only interpret the smoothed record of reconstructed SSS (Figure 2c), which we just regard as a qualitative estimate. The smoothed paleosalinity reconstruction indicates an increase from minimum values near 7000 B.P. toward a 
middle Holocene maximum near 5500 B.P., when paleosalinities were $\sim 1.5 \mathrm{psu}$ above modern values. Thereafter paleosalinities generally declined toward the late Holocene including several short-term fluctuations which generally parallel short-term variations in paleotemperatures (Figure 2).

[20] Both paleoproductivity proxy records (biogenic opal and $\mathrm{C}_{\text {org }}$ contents) show a significant long-term increase during the last 8000 years from around $2.5 \mathrm{wt} \%$ to $>4 \mathrm{wt} \%$ for biogenic opal (Figure 3d) and from $\sim 1.5$ to $2.4 \mathrm{wt} \%$ for $\mathrm{C}_{\text {org }}$ (Figure 3e). This increase was enhanced during the last 1500-2000 years. Two century-scale intervals between 5500 and 5000 B.P. and shortly after 4000 B.P. show prominent excursions to higher values within the long-term increasing trend. A significant effect of higher $\mathrm{C}_{\text {org }}$ preservation toward the core top is unlikely because the biogenic opal record generally parallels that of $\mathrm{C}_{\mathrm{org}}(r=0.82)$, implying a dominant control of opal-producing organisms in the production of organic carbon (Figures $3 \mathrm{~d}$ and $3 \mathrm{e}$ ).

\subsection{Long-Term Paleoceanographic History During the Middle and Late Holocene}

[21] Paleotemperature, paleosalinity, and paleoproductivity estimates for the southern PCC show a significant longterm trend which corresponds to continental rainfall changes. We attribute this long-term evolution primarily to (1) latitudinal displacements of the ACC and the southern westerly wind belts possibly caused by insolation-induced long-term changes in large-scale Southern Hemisphere atmospheric circulation patterns (e.g., Hadley cell intensity) and (2) global SST variations due to planetary albedo changes combined with long-term variations in the strength of the Atlantic thermohaline circulation leading to temperature changes especially around Antarctica.

[22] Higher paleotemperatures and salinities coinciding with lower paleoproductivity (Figure 3) during the middle Holocene (8000-4000 B.P.) most likely indicate a decreased advection of cold and nutrient-rich subpolar water masses through the ACC combined with diminished advection of low-salinity CFW and/or reduced supply of freshwater and micronutrients to the Chilean fjord region through decreased continental rainfall. Reduced precipitation in the middle Holocene is corroborated by the Fe record of core GeoB 3313-1 (Figure 3a), which serves as a proxy for continental rainfall in southern Chile [Lamy et al., 2001]. Together with continental paleoclimate records from both central Chile $\left(33^{\circ} \mathrm{S}\right)$ [Villagrán and Varela, 1990; Lamy et al., 1999; Jenny et al., 2002] and southern Chile $\left(43^{\circ} \mathrm{S}\right)$ [Villagrán, 1990] this record indicates reduced rainfall during the middle Holocene, most likely caused by a poleward shift of the Southern Westerlies. As the modern location of this wind belt is strongly related to the steepest SST gradients within the ACC [Streten and Zillman, 1984], less advection of ACC-derived water masses most likely implies a farther southward location of this current system.

[23] A southward shift of both the Southern Westerlies and the ACC during the middle Holocene is consistent with paleodata from the South American tropics and Antarctica. Records from the South American Altiplano indicate increased aridity related to a more intense Hadley cell due to reduced austral summer insolation during this time span
[Thompson et al., 1998; Cross et al., 2000]. The intensification of the Hadley cell might have led to a farther southward shift of the Southern Westerlies [Lamy et al., 2001]. Antarctic ice core data from the Ross Sea sector show a temperature maximum between 7000 and 5000 B.P. [Masson et al., 2000], coinciding with maximum paleotemperatures and paleosalinities in the southern PCC. Ice core data from Taylor Dome and marine sediment records from the Palmer Deep site off the Antarctic Peninsula likewise indicate higher temperatures and decreased sea ice during this period, which probably reflects a poleward shift of circumpolar air and water masses [Stager and Mayewski, 1997; Steig et al., 1998; Domack et al., 2001]. A southward shift of the Southern Westerlies and the ACC during the middle Holocene might have been additionally related to reduced seasonal insolation differences during this time span, resulting in less northward movement of the westerlies during winter [Markgraf et al., 1992] (Figure 3f).

[24] Reconstructed Holocene paleotemperatures, however, reach up to $16.2^{\circ} \mathrm{C}$ in the middle Holocene, and mean annual SSTs of $16.2^{\circ} \mathrm{C}$ are today found at $\sim 31^{\circ} \mathrm{S}$ within the PCC [Levitus and Boyer, 1994], which would imply a latitudinal northward shift of $\sim 10^{\circ}$ of the PCC system through the last 5500 years. Compared to an estimated $5^{\circ}$ latitudinal shift of the southern westerly wind belt in Chile since the Last Glacial Maximum [Heusser, 1989; Lamy et al., 1998], a $10^{\circ}$ latitudinal displacement of marine current systems during the Holocene seems quite unrealistic. Therefore part of the observed warming of surface waters is probably related to a general warming of the southeast Pacific. Results of a coupled atmosphere-ocean-vegetation model [Ganapolski et al., 1998] indicate a general global warming during the middle Holocene due to a decrease of the planetary albedo in spite of opposite insolation changes on both hemispheres. Furthermore, the model results indicate a middle Holocene warming and freshening of the North Atlantic which might have caused a reduction of the Atlantic thermohaline circulation, resulting in a warming of up to $2^{\circ} \mathrm{C}$ near Antarctica [Ganapolski et al., 1998]. This temperature increase probably also affected paleotemperatures in the southern PCC.

[25] After the middle Holocene maximum, paleotemperatures and paleosalinities generally decrease, while biogenic opal and $\mathrm{C}_{\text {org }}$ contents point to increasing biological productivity of the southern PCC (Figures $3 \mathrm{~b}-3 \mathrm{e}$ ). The most significant increase in paleoproductivity occurred after $\sim 1500$ B.P., coinciding with the strengthened cooling of the surface waters by $\sim 1.4^{\circ} \mathrm{C}$. (Figures $3 \mathrm{~b}, 3 \mathrm{~d}$, and $3 \mathrm{e}$ ). These data are consistent with Antarctic ice core data from Taylor Dome and marine sediment records from Palmer Deep, which likewise show a trend toward lower temperatures and/or increasing sea ice as well as increased ice-rafted detritus input during the late Holocene [Steig et al., 1998; Domack et al., 2001]. Continental rainfall increased during the late Holocene (since 4000 B.P.) in both central Chile $\left(33^{\circ} \mathrm{S}\right)$ [Villagrán and Varela, 1990; Heusser, 1990; Lamy et al., 1999] and southern Chile $\left(41^{\circ}-43^{\circ} \mathrm{S}\right)$ [Villagrán, 1990; Lamy et al., 2001] (Figure 3a). The decreasing paleotemperatures and increasing continental precipitation point to an equatorward shift of both the ACC and the southern westerly 


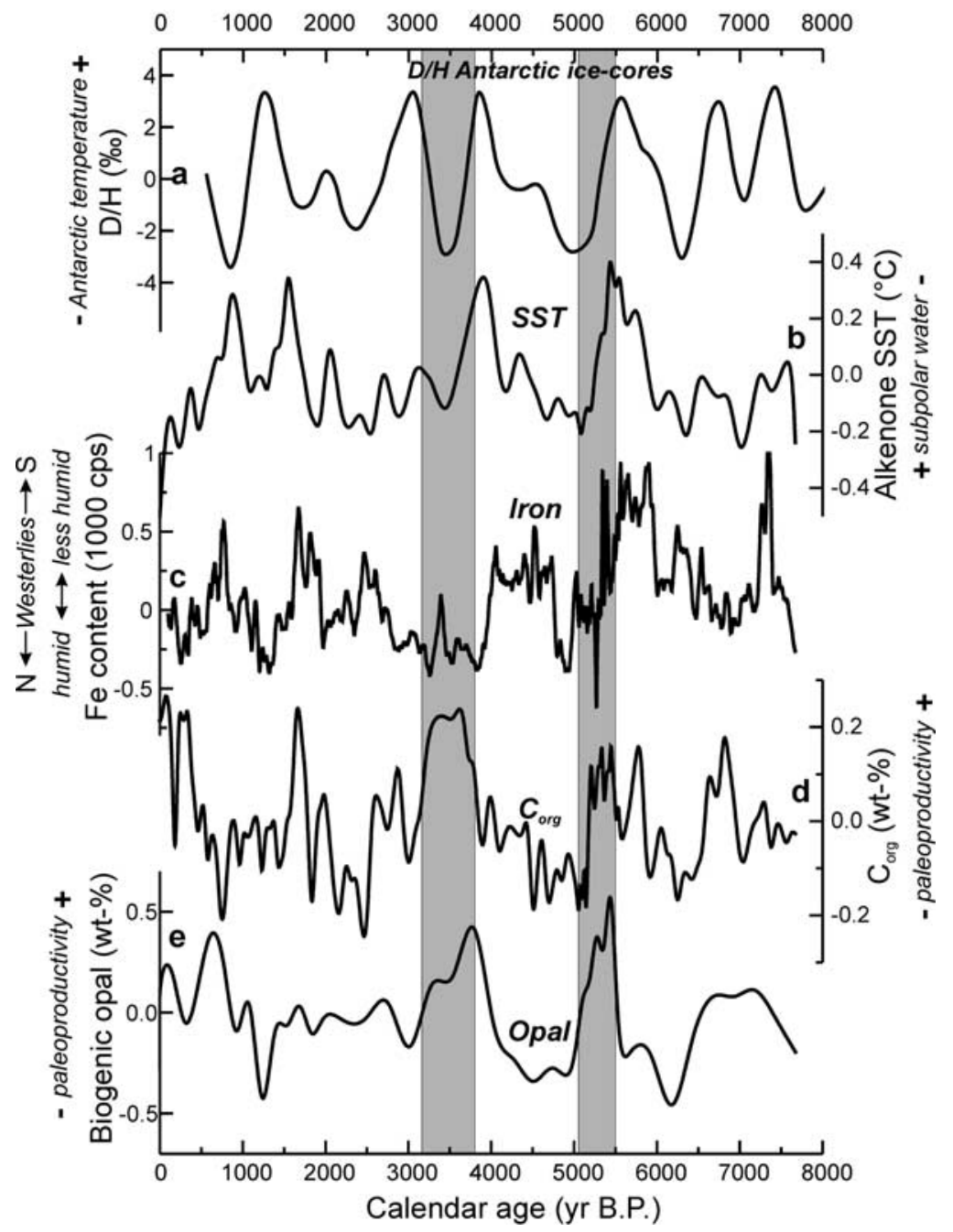

Figure 4. Comparison between millennial- to multicentennial-scale changes of paleoceanographic and continental paleoclimate records and climatic changes in Antarctica. (a) Millennial-scale variability in Antarctic temperature [Masson et al., 2000]. First component of an empirical orthogonal function (EOF) analysis is calculated from isotopic records from the Ross Sea sector (Byrd and Taylor Dome sites). Long-term trends (first component of a singular spectrum analysis (SSA)) are subtracted. (b) Paleotemperatures from core GeoB 3313-1 (long-term trend shown in Figure 3b subtracted). Paleotemperatures off Chile show a significant positive correlation $(r=0.57, n=57$; significant on the $99.9 \%$ level after applying a 100 year time resolution interpolation) to Antarctic temperatures until 2000 B.P. (c) Iron contents of core GeoB 3313-1 [Lamy et al., 2001], indicating rainfall and the position of the Southern Westerlies (long-term trend shown in Figure 3a subtracted). Paleoproductivity proxies of (d) $\mathrm{C}_{\text {org }}$ content and (e) biogenic opal content (long-term trends shown in Figures $3 \mathrm{~d}$ and $3 \mathrm{e}$ subtracted). Vertical shaded bars mark time intervals of century-scale increases in paleoproductivity as discussed in the text.

wind belt during the late Holocene toward their modern position. The increased supply of cold and nutrient-rich surface waters with the ACC coinciding with intensified continental rainfall resulted in enhanced discharge of freshwater and continent-derived micronutrients, which led to higher biological productivity in the late Holocene.

\subsection{Millennial- to Multicentennial-Scale Variability}

[26] Recent studies have shown that the Holocene climate in different parts of the world is highly variable on millen- nial to multicentennial timescales [e.g., Bond et al., 1997; deMenocal et al., 2000; Arz et al., 2001]. Also, in southern Chile the changes in continental rainfall, as deduced from the terrigenous sediment composition of core GeoB 3313-1, reveal a significant short-term variability during the Holocene most likely induced by latitudinal shifts of the Southern Westerlies [Lamy et al., 2001] (Figure 4c). The paleoceanographic proxy records of core GeoB 3313-1 presented in this study likewise show millennial- to multicentennial-scale variability (Figure 4). As today storm 
tracks of the Southern Westerlies are related to the steepest SST gradients within the polar front, we assume that past latitudinal shifts of the Southern Westerlies were connected to similar latitudinal shifts of the ACC. This implies that a southward displacement of the westerlies was associated with higher SSTs and lower productivity comparable to the long-term trend (see section 4.2). The pattern of the shorterterm variability, however, is more complex, and many of the multicentennial- to millennial-scale variations in paleotemperatures and paleosalinities do not exactly match the reconstructed shifts of the westerlies (Figure 4). After the Holocene "optimum" near 5500 B.P., prominent paleotemperature and paleosalinity maxima occurred at $\sim 4000$ and 1500 B.P. and lag rainfall minima by $\sim 100$ years, whereas other short-term peaks of the paleotemperature and paleosalinity records seem to lead the rainfall minima (e.g., at $\sim 2700$ and 900 B.P.) (Figures $4 \mathrm{~b}$ and $4 \mathrm{c}$ ).

[27] These mismatches might be related to a different impact of low-latitude (including El Niño-Southern Oscillation (ENSO)) and high-latitude factors controlling continental rainfall and paleoceanographic changes, respectively. A comparison of the short-term variability in our paleotemperature record to the millennial-scale temperature signal in combined deuterium records in Holocene ice cores from the Ross Sea sector, Antarctica [Masson et al., 2000], reveals a significant correlation $(r=0.57)$ at least until $\sim 2000$ B.P. (Figures $4 \mathrm{a}$ and $4 \mathrm{~b}$ ). Thereafter, the records are out of phase, probably because the Ross Sea sector ice core records are disturbed by local processes. Other Antarctic ice core records and marine sediment data from Palmer Deep show a pronounced Holocene cold spell near 400 B.P. (Antarctic Little Ice Age [Masson et al., 2000]) and between $~ 700$ and 100 B.P., respectively, which is more consistent with the strong cooling of the southern PCC after a short warm spell at $\sim 900$ B.P. (Figure $4 b$ ). This coincidence of short-term temperature changes in Antarctic, and the southern PCC suggests a predominating high-latitude control of paleotemperature changes within the southern PCC on millennial to multicentennial timescales during the Holocene. Short-term continental rainfall changes as shown by the Fe record of core GeoB 3313-1 (Figure 4c), on the other hand, appear to be closely related to changes within the tropical climate system, i.e., the Hadley cell intensity [Lamy et al., 2001]. Possibly related to the onset of the modern state of the ENSO system, continental rainfall shifts in southern Chile and temperature changes in Antarctica become out of phase at the beginning of the late Holocene [Lamy et al., 2001]. This is consistent with both long-term paleo-ENSO records [e.g., Sandweiss et al., 1996; Shulmeister and Lees, 1995] and ENSO modeling studies [Clement et al., 1999]. As SST anomalies during modern ENSO events only reach south up to $33^{\circ}-36^{\circ} \mathrm{S}$ [Strub et al., 1998], paleotemperatures in the southern PCC during the late Holocene are most likely not affected by changes of ENSO. In contrast to this, rainfall in central and southern Chile was probably strongly influenced by ENSO events as indicated by meteorological studies [Ruttland and Fuenzalida, 1991]. The mismatch of millennial- to multicentennial-scale variability in atmospheric (i.e., Southern Westerlies) and oceanographic (i.e., southern PCC and ACC) circulation patterns, especially during the late
Holocene, might thus partly be related to long-term changes in ENSO.

[28] A combination of the above-discussed low- and highlatitude forcing factors is thus most likely responsible for the observed short-term paleoproductivity changes within the southern PCC. The paleoproductivity records (Figures $4 \mathrm{~d}$ and $4 \mathrm{e}$ ) exhibit two century-scale excursions to higher values between 5500 and 5000 B.P. and shortly after 4000 B.P. which do not exactly coincide with SST minima. Instead, they occur during cooling phases shortly after the two most significant increases in rainfall in the continental hinterland (Figures $3 \mathrm{a}$ and $4 \mathrm{c}$ ). The Fe record indicates that these rainfall augmentations terminated the middle Holocene less humid phase in southern Chile (Figure 3a). This points to a significant contribution of continent-derived micronutrients which resulted in an increase of marine productivity off southern Chile for several centuries. Holocene paleoproductivity changes on millennial to multicentennial timescales off southern Chile are therefore controlled by both primarily high-latitude forced shifts of the ACC (as indicated by the paleotemperature record) and latitudinal shifts of the Southern Westerlies, which are mainly controlled by changes within the tropical climate system [Lamy et al., 2001].

\section{Conclusions}

[29] Paleoceanographic proxy data from a marine sediment core off southern Chile $\left(41^{\circ} \mathrm{S}\right)$ show a significant longterm trend during the last 8000 years. Paleotemperatures and paleosalinities within the southern PCC increase toward a middle Holocene maximum shortly after 6000 B.P. Thereafter, both paleotemperatures and paleosalinities tend to decline, more pronounced after $\sim 1500$ B.P. Paleoproductivity steadily rose throughout the last 8000 years, likewise with a stronger increase after $\sim 1500$ B.P. These long-term trends coincide with increasing rainfall and a general northward movement of the Southern Westerly wind belt during the middle and late Holocene and point to a common longterm response of atmospheric and oceanographic circulation patterns off southern Chile during the Holocene.

[30] Millennial- to multicentennial-scale variability in paleotemperatures and paleoproductivity mostly lags changes in rainfall and thus displacements in the position of the Southern Westerlies. Paleotemperature fluctuations in the southern PCC, however, significantly coincide with millennial-scale climate changes in Antarctica. This indicates a predominate high-latitude control of latitudinal shifts of the ACC at shorter timescales which resulted in the advection of cool and nutrient-rich subpolar water masses. Additionally, continent-derived micronutrients supplied by increased river discharge might have enhanced marine productivity, especially after the two major rainfall increases at $\sim 5500$ and 4000 B.P.

[31] Latitudinal shifts of the Southern Westerlies are primarily controlled by changes within the tropical climate system [Lamy et al., 2001] which dominate over the Antarctic influence, especially during the last 4000 years, while the Peru-Chile Current system seems to be still controlled by high latitude processes. During the middle 
Holocene, on the other hand, especially at the Holocene "optimum" (shortly after 6000 B.P.), both oceanographic and atmospheric patterns appear to change in phase.

[32] Acknowledgments. We thank the captain and crew of R/V Sonne for their excellent help in collecting the samples. M. Segl and B. MeyerSchack are acknowledged for performing the stable isotope measurements,
Dietmar Grotheer and Ralph Kreutz are thanked for technical assistance with gas chromatography, and P. Grootes and staff of the Leibniz-Labor in Kiel are thanked for providing AMS ${ }^{14} \mathrm{C}$ datings. We are grateful to Valerie Masson for providing Antarctic ice core data. M. Marchant and two anonymous reviewers made important suggestions which improved the manuscript. Financial support was made available by the German Bundesministerium für Bildung und Forschung through funding the project CHIPAL (03G0102A) and by the Deutsche Forschungsgemeinschaft through the Research Centre Ocean Margins (RCOM).

\section{References}

Alheit, J., and P. Bernal, Effects of physical and biological changes on the biomass yield of the Humboldt Current ecosystem, in Large Marine Ecosystems, vol. V, Stress, Mitigation and Sustainability, edited by K. Sherman, L. M. Alexander, and B. D. Gold, pp. 55-68, Am. Assoc. for the Adv. of Sci., Washington, D. C., 1993.

Arz, H. W., S. Gerhardt, J. Pätzold, and U. Röhl, Millennial-scale changes of surface- and deepwater flow in the western tropical Atlantic linked to Northern Hemisphere high-latitude climate during the Holocene, Geology, 29, 239-242, 2001.

Berger, A., and M. F. Loutre, Insolation values for the climate of the last 10 million years, Quat. Sci. Rev., 10, 297-317, 1991.

Bond, G., W. Showers, M. Cheseby, R. Lotti, P. Almasi, P. deMenocal, P. Priore, H. Cullen, I. Hadjas, and G. Bonani, A pervasive millennial-scale cycle in North Atlantic Holocene and Glacial climates, Science, 278, 12571266, 1997.

Brandhorst, W., Condiciones oceanográficas extivales frente a la costa de Chile, Rev. Biol. Mar. Valparaiso, 14, 45-84, 1971.

Clement, A. C., R. Seager, and M. A. Cane, Orbital controls on the El Niño/Southern Oscillation and the tropical climate, Paleoceanography, 14, 441-456, 1999.

Cross, S. L., P. A. Baker, G. O. Seltzer, S. C. Fritz, and R. B. Dunbar, A new estimate of the Holocene lowstand level of Lake Titicaca, central Andes, and implications for tropical pelaeohydrology, Holocene, 10, 21-32, 2000.

Delaygue, G., J. Jouzel, and J.-C. Dutay, Oxygen 18-salinity relationship simulated by an oceanic general circulation model, Earth Planet. Sci. Lett., 178, 113-123, 2000

DeMaster, D. J., The supply and accumulation of silica in the marine environment, Geochim. Cosmochim. Acta, 45, 1715-1732, 1981.

deMenocal, P., J. Ortiz, T. Guilderson, and M. Sarnthein, Coherent high- and low-latitude climate variability during the Holocene warm period, Science, 288, 2198-2202, 2000.

Domack, E., A. Leventer, R. Dunbar, F. Taylor, S.Brachfeld, and C. Sjunneskog, ODP Leg, 178 Scientific Party, Chronology of the Palmer Deep site, Antarctic Peninsula: A Holocene palaeoenvironmental reference for the circumAntarctic, Holocene, 11, 1-9, 2001.

Duplessy, J.-C., J. Laberyie, A. Juillet-Leclerc, F. Maitre, J. Duprat, and M. Sarnthein, Surface salinity reconstruction of the North Atlantic Ocean during the Last Glacial Maximum, Oceanol. Acta, 14(4), 311-324, 1991.

Fairbanks, R. G., C. D. Charles, and J. D. Wright, Origin of global meltwater spikes, in Radiocarbon After Four Decades, edited by R. E. Taylor, pp. 473-500, Springer-Verlag, New York, 1992.

Ganapolski, A., C. Kubatzki, M. Claussen, V. Brovkin, and V. Petoukhov, The influence of vegetation-atmosphere-ocean interaction on climate during the mid-Holocene, Science, 280, 1913-1919, 1998

Hebbeln, D., G. Wefer, and Cruise Participants, Cruise report of R/V SONNE cruise 102, $\mathrm{Val}$ paraiso-Valparaiso 9.5.-28.6.95., $126 \mathrm{pp}$. Univ. of Bremen, Bremen, Germany, 1995.

Hebbeln, D., M. Marchant, T. Freudenthal, and G. Wefer, Surface sediment distribution along the Chilean continental slope related to upwelling and productivity, Mar. Geol., 164, 119 137,2000 .

Hebbeln, D., M. Marchant, and G. Wefer, Paleoproductivity in the southern Peru-Chile Current through the last 33,000 years, Mar. Geol., in press, 2002.

Heusser, C. J., Southern westerlies during the Last Glacial Maximum, Quat. Res., 31, $423-$ $425,1989$.

Heusser, C. J., Ice age vegetation and climate of subtropical Chile, Palaeogeogr. Palaeoclimatol. Palaeoecol., 80, 107-127, 1990.

Jenny, B., B. L. Malero-Garcés, R. Villa, R. Urrutia, M. Geyh, and H. Veit, Evidence for an early to mid-Holocene aridity in central Chile $\left(34^{\circ} \mathrm{S}\right)$ related to the Southern Westerlies: The Laguna Aculeo record, Quat. Res., in press, 2002

Kim, J., R. R. Schneider, D. Hebbeln, P. J. Müller, and G. Wefer, Alkenone-derived high-resolution sea surface temperature reconstruction in the eastern South Pacific off mid-latitude Chile over the past $33 \mathrm{kyr}$, Quat. Sci. Rev., in press, 2002.

Klump, J., D. Hebbeln, and G. Wefer, High concentration of biogenic barium in Pacific sediments after Termination I: A signal of changes in productivity and deep water chemistry, Mar. Geol., 177, 1-11, 2001.

Lamy, F., D. Hebbeln, and G. Wefer, Late Quaternary precessional cycles of terrigenous sediment input off the Norte Chico, Chile $\left(27.5^{\circ} \mathrm{S}\right)$ and paleoclimatic implications, Palaeogeogr. Palaeoclimatol. Palaeoecol., 141, 233-251, 1998

Lamy, F., D. Hebbeln, and G. Wefer, High resolution marine record of climatic change in midlatitude Chile during the last 28,000 years based on terrigenous sediment parameters, Quat. Res., 51, 83-93, 1999.

Lamy, F., D. Hebbeln, U. Röhl, and G. Wefer, Holocene rainfall variability in southern Chile: A marine record of latitudinal shifts of the Southern Westerlies, Earth Planet. Sci. Lett., 185, 369-382, 2001.

Levitus, S., and T. Boyer, World Ocean Atlas, vol. 4, Temperature, NOAA Atlas NESDIS 4 , 117 pp., Natl. Oceanic and Atmos. Admin. Silver Spring, Md., 1994.

Marchant, M., D. Hebbeln, and G. Wefer, High resolution planktic foraminiferal record of the last 13,300 years from the upwelling area off Chile, Mar. Geol., 161, 115-128, 1999.

Markgraf, V., J. R. Dodson, P. A. Kershaw, M. S. McGlone, and N. Nicholls, Evolution of late Pleistocene and Holocene climates in the cir-
cum-South Pacific land areas, Clim. Dyn., 6 , 193-211, 1992.

Masson, V., et al., Holocene climate variability in Antarctica based on 11 ice-core isotopic records, Quat. Res., 54, 348-358, 2000.

Müller, P. J., and R. Schneider, An automated leaching method for the determination of opal in sediments and particulate matter, Deep Sea Res., 40, 425-444, 1993.

Prahl, F. G., L. A. Muehhausen, and D. L. Zahnle, Further evaluation of long-chain alkenones as indicators of paleoceanographic conditions, Geochim. Cosmochim. Acta, 52, 2303-2310, 1988.

Rostek, F., G. Ruhland, F. C. Bassinot, P. J. Müller, L. D. Labeyrie, Y. Lancelot, and E. Bard, Reconstructing sea surface temperature and salinity using $\delta^{18} \mathrm{O}$ and alkenone records, Nature, 364, 319-321, 1993.

Rühlemann, C., S. Mulitza, P. J. Müller, G. Wefer, and R. Zahn, Warming of the tropical Atlantic Ocean and slowdown of thermohaline circulation during the last deglaciation, Nature, 402, 511-514, 1999

Ruttland, J., and H. Fuenzalida, Synoptic aspects of the central Chile rainfall variability associated with the Southern Oscillation, Int. J. Climatol., 11, 63-76, 1991.

Sandweiss, D. H., J. B. Richardson III, E. J Reitz, H. B. Rollins, and K. A. Maasch, Geoarchaeological evidence from Peru for a 5000 years B.P. onset of El Niño, Science, 273, 1531-1533, 1996.

Shackleton, N., Attainment of isotopic equilibrium between ocean water and the benthonic foraminifera genus Uvigerina: Isotopic changes in the ocean during the last glacial, Colloq. Int. CNRS, 219, 203-209, 1974.

Shulmeister, J., and B. G. Lees, Pollen evidence from tropical Australia for the onset of an ENSO-dominated climate at c. 4000 B.P., Holocene, 5, 10-18, 1995 .

Stager, J. C., and P. A. Mayewski, Abrupt early to mid-Holocene climatic transition registered at the equator and the poles, Science, 276 , 1834-1836, 1997

Steig, E. J., C. H. Hart, J. W. C. White, W. L. Cunningham, M. D. Davis, and E. S. Saltzman, Changes in climate, ocean and ice-sheet conditions in the Ross embayment, Antarctica at $6 \mathrm{ka}$, Ann. Glaciol., 27, 305-310, 1998.

Streten, N. A., and J. W. Zillman, Climate of the South Pacific, in Climates of the Oceans, edited by H. van Loon, pp. 26-429, Elsevier Sci., New York, 1984

Strub, P. T., J. M. Mesias, V. Montecino, J. Ruttlant, and S. Salinas, Coastal ocean circulation off western South America, in The Global Coastal Ocean: Regional Studies and Syntheses, edited by A. R. Robinson and K. H. Brink, pp. 273-315, John Wiley, New York, 1998.

Stuiver, M., and P. J. Reimer, Extended ${ }^{14} \mathrm{C}$ database and revised calib 3.0 C-14 age calibration program, Radiocarbon, 35, 215-230, 1993. 
Thomas, A. C., F. Huang, P. T. Strub, and C. James, Comparison of the seasonal and interannual variability of phytoplankton pigment concentrations in the Peru and California Current systems, J. Geophys. Res., 99, 73557370, 1994.

Thompson, L. G., et al., A 25,000 year tropical climate history from the Bolivian ice cores, Science, 282, 1858-1864, 1998.

Villagrán, C., Glacial climates and their effects on the history of the vegetation of Chile: A synthesis based on palynological evidence from Isla de Chiloé, Rev. Palaeobot. Palynol., 65, 17-24, 1990.

Villagrán, C., and J. Varela, Palynological evidence for increased aridity on the central Chilean coast during the Holocene, Quat. Res., 34, 198-207, 1990

Wolff, T., S. Mulitza, H. Arz, J. Pätzold, and G. Wefer, Oxygen isotopes versus CLIMAP (18 ka) temperatures: A comparison from the tropical Atlantic, Geology, 26, 675-678, 1998.

F. Lamy, C. Rühlemann, D. Hebbeln, and G. Wefer, Fachbereich Geowissenschaften, Universität Bremen, Postfach 3304 40, 28334 Bremen, Germany. (flamy@uni-bremen.de) 